\title{
The Journal of ysm
}

Laryngology and Otology

\author{
EDITED BY \\ WALTER HOWARTH
}

ASSISTANT EDITOR

R SCOTT STEVENSON

WITH THE COLLABORATION OF

G.H.BATEMAN V.E. NEGUS R. G. MACBETH

\section{Contents}

AN INTroduction to THE STUDY OF THE COMPARATIVE

ANATOMY OF THE LABYRINTH

OLIVER GraY

FX̃ostosis of the EXterNal Auditory Mratus

D. F. N. HARRISON

AdamaNthNomas IN RELATION TO THE NOSE

AHMAD BEX HANDOUSA

LARYNGOCELES

S. HOROWIIZ

CIANicat RECORDS-

A CXST OF THE LARYNCEAL VENTRTCLE

J. I. MUNRO BLACK

An Unusuat Medico-Liggal Trauma

AHMAD EL-HAKEEM

SOCHETES' PROCHEDINGS:-

Royal SocIeTy of MEDTCINe-Section OF LARYAGOLOGY

Asstructs

THE EArR

THE JaRXNX

- Genbarain Notirs

$4 \div \because \because$ London

Headley Brothers Ltd I0.9. Kingsway W.C.

Monthly, $7 / 6$ net post free i Minual Subscriptions $£ 3 / 3 / 0$ net S. 150.02215100010616 Published online,by Campridge University Press. 


\title{
The Journal of \\ Laryngology and Otology
}

(Founded in 1887 by Morel. Mackenzis and Norrts Wourenden) EDITED BY

\section{WALTER HOWARTH}

\author{
ASSISTANT EDITOR
}

R. SCOTT STEVENSON

\section{G. H. BATEMAN \\ WITH THE COLIABORATION OF}

1. Original Articles are accepted on the condition that they have not been published elsewhere.

2. Manuscripts should be typewritten, on one side only of the paper, and well spaced.

The Harvard system of recording references should be used, e.g. Green, G., and Brown, D. (1951) $\mathcal{7}$. Laryng. and Otol., 65, 33 .

It is most imporiant that authors should verify personally the accuracy of every reference before submitting a paper for publication.

3. Galley proofs and engraver's proofs of illustrations are sent to the author. Corrections, which should be kept to a minimum, must be clearly marked, and no additional matter added.

4. Blocks illustrating articles are normally paid for by the foumal. Authors may, however, be required at the Editor's discretion, to contribute towards the cost of these in cases where this is particularly heavy.

5. Orders for reprints should be sent when returning galley proofs, and for this purpose special forms are supplied.

6. Authors of original communications on Oto-Laryngology in other journals are invited to send a copy, or two reprints, to the foumal of Laryngology. If they are willing, at the same time, to submit their own abstract (in English, French, Italian, or German) it will be welcomed.

7. Editorial communications may be addressed to THE EDrror, Joumal of Laryngology, c/o HEADLEX BroTHERs LTD, 109 Kingsway London W C.2.

8. The annual subscription is three guineas sterling, post free, and is payable in advance.

9. Single copies will be on sale at $75.6 \mathrm{~d}$. cach ; copies of parts up to Vol. LXIII may be purchased at 4 s. each.

10. All subscriptions, advertising and business communications should be sent to the publishers, HeAdiex Brotures LTD, 109 Kingsway London $\mathrm{WC}_{2}$.

United States of Ameriva

Orders for this fournal may be sent either through a local bookseller, or to Messrs. G. E. StrecurerT \& Co., $31-33$ East 1 oth Street, New York, or they may be sent direct to the publishers; HeAdlex Brothers LTD, tog Kingsway London $\mathrm{W}_{2}$, England.

Please mention The Josinal of Larynglogy when replying to advertisements 


\section{AMPLIVOX MODEL 6I THE CLINICAL AUDIOMETER OF INTERNATIONAL REPUTE}

"Messrs. Amplivox were among the first firms to produce an audiometer in this country, and their larger model is one of the best instruments of the kind now made in the world at a competitive price." -The LANCET, 23-12-50.

- Eleven exact test frequencies 125-12,000 c.p.s.

- Simplified hearing loss dial. The same set of figures is read for both bone and air conduction at all frequencies, and for speech.

- Bone conduction tests can be made from 125-4,000 c.p.s.

- Masking Tone calibrated in decibels, permitting accurate control of masking.

- Double Air receivers enable test tones to be switched instantly from ear to ear.

- Speech test circuit monitors speech level, permitting accurate measurement of hearing loss for speech.

- Loudness Balance Control establishes presence of recruitment in monaural deafness.

- Automatic voltage compensator.

Recruitment Test Set accessory establishes presence of recruitment by amplitude modulation, enabling each ear to be tested independently.

Speech Turntable and Englishmade Harvard Spondee records also available.

Full details are available from the manufacturers who will gladly arrange demonstrations if required.

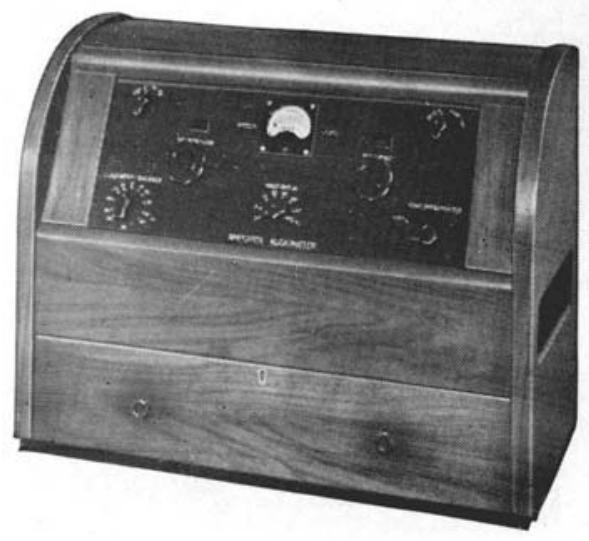

\section{The Basic Instrument of Modern Otology}

ACCURATE • COMPLETE • SIMPLE TO OPERATE

AMPLIVOX LTD., 2 BENTINCK ST., LONDON, W.I (Welbeck 259I)

Please mention The Journal of Laryngology when replying to advertisements 


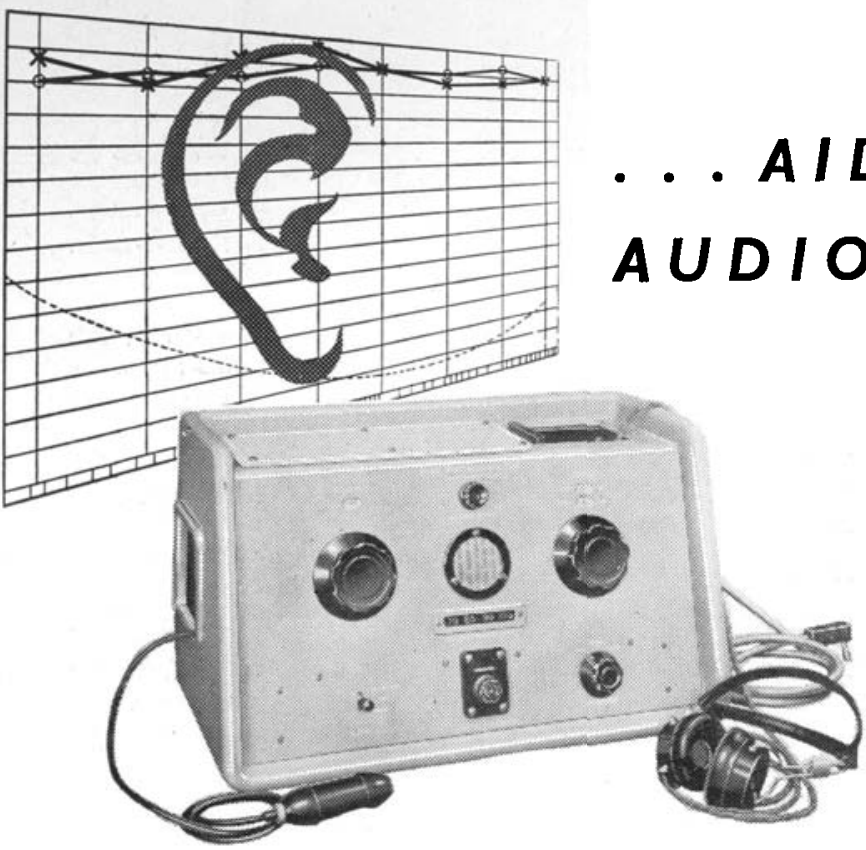

The Marconi Pure Tone Audiometer was developed to meet the specifications of the Medical Research Council's Committee on Electro-Acoustics. Every instrument, by careful calibration against N.P.L. determinations, can be relied on to be functionally interchangeable with any other of this type. The patient, is instructed by crystal microphone and high fidelity ear-phones, and responds to tests by operating a signal lamp on the instrument. Sound output over the normal hearing range is automatically corrected for characteristic losses.

\section{THE PURE TONE A udiometer \\ Type TF 895}

For full particulars of this efficient aid to audiometry please write:

\section{$M A R C O N I$ instruments}

MARCONI INSTRUMENTS LTD., ST. ALBANS, HERTFORDSHIRE

Telephone: St. Albans 6161/7

Marconi House, Pudding Chare, Newcastle on Tyne . 233 St. Vincent Street, Glasgow . Marconi House, 38 Pall Mall, Liverpool . Marconi House, Mount Stuart Square, Cardiff . 19 The Parade, Leamington Spa • 41 Donegall Place, Belfast 


\title{
PRESCRIBE THE EASY EFFECTIVE METHOD
}

When spraying, the patient can hold his head in a natural position, yet the solution spreads throughout the nasal cavity, assuring thorough treatment. Effective dropper-application, on the other hand, requires a complicated posture technique which patients are apt to neglect in home treatment.
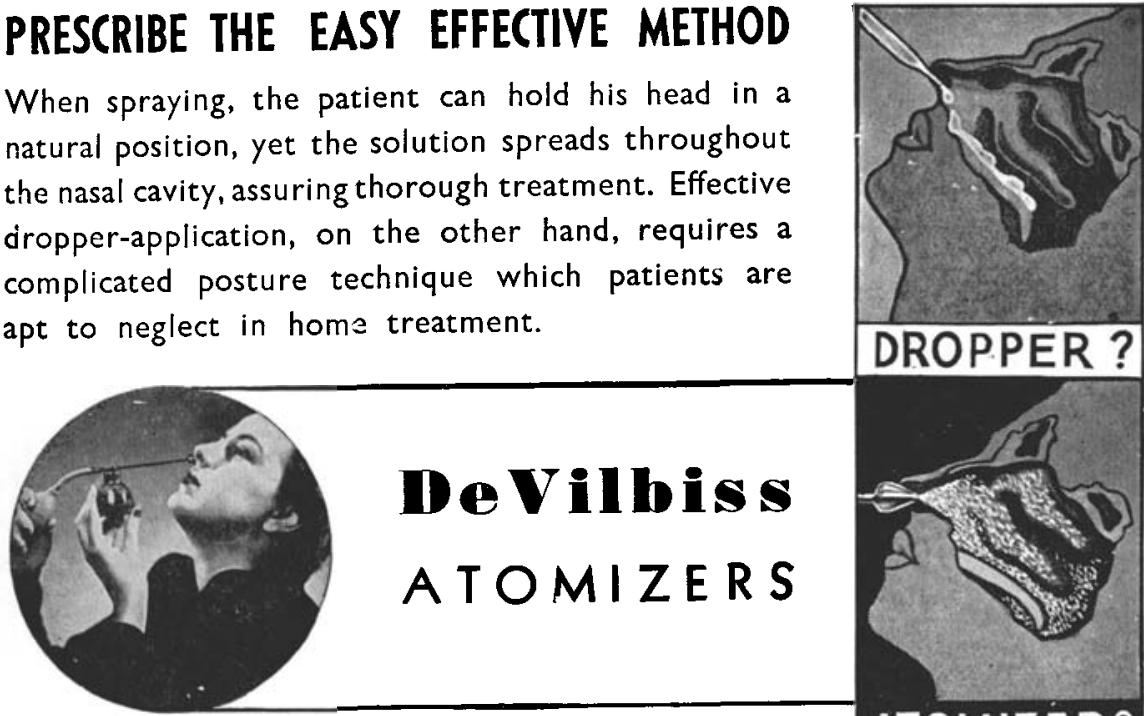

These illustrations, which are based on X-ray research, clearly demonstrate the advantages of the atomizer as compared with the dropper

The AEROGRAPH Co., Ltd., Lower Sydenham, London, S.E.26 Sole Distributors of DeVilbiss Products in the United Kingdom. Telephones: Sydenham 6060-8 Lines.

\section{Mail Your Order Now! PROBLEMS OF THE DEAF}

\author{
By MAX A. GOLDSTEIN, M.D., F.A.C.S. \\ 6ro Pages-273 Illustrations-Leather Bound \\ $\$ 6.00$ Postage prepaid
}

An unusual, authoritative and comprehensive volume of XIX chapters, covering every phase of work with the Deaf, Deafened and Speech Defective, by an otologist and teacher of 40 years' experience, including :

Chronological History of Deafness-Anatomy and Physiology-Mechanics of Speech - Speech Defects - Cerebral Localization-Hearing Tests - Methods of Instruction-The Acoustic Method-Training of Teachers-The Deaf Child-Hardof-Hearing Child-Physician and Deaf Child-Parent of Deaf Child-Deafened Adult-Hearing Aids-Schools for the Deaf-Quacks and Quackeries-Research.

\section{Published by THE LARYNGOSCOPE PRESS} 640 South Kingshighway

ST. LOUIS, MO.

Please mention The Journal of Larynology when replying to advertisements 


\section{CONTENTS}

An Introduction to the Study of the Comparative Anatomy of the Labyrinth. Oliver Gray (Haslemere) . .

Exostosis of the External Auditory Meatus. D. F. N. Harrison (London)

Aldamantinomas in Relation to the Nose. Ahmad Bey Handousa (Cairo) . $\quad . \quad$. $\quad . \quad$. . .

LARYxGocrees. S. Horowitz (Glasgow) . . . . 72

Clinical. Recorios-

A Cyst of the Laryngeal Ventricle. J. I. Munro Black (Newcastle-on-Tyne)

An Unusual Medico-Legal Trauma. Ahmad El-Hakeem (Abbassia)

Societies' Proceedings-

Royal Society of Medicine-Section of Laryngology . $\quad$ • $\quad 73^{8}$

\section{Abstracts-.}

Ear Prophylactic and Therapeutic control of Vestibular disturbances with Dimen hydrinate. I_eslie N. Gay.

larynx .

Treatment of Tuberculosis of the larynx by Chemotherapy. Linden J. Wallner, George C. Turner, Meyer C. Lichtenstein and Henry C. Sweany.

Miscellaneous .

Metastatic Adrenomedulloblastoma of the Pterygopalatine Fossa. w. O. Lodge and M. Brookes; Purulent Parotitis in the Newborn. W. Kisch; Atiology of Aspirin Bleeding. J. MacLean Smith and J. Mackinnon; Bell's Palsy, Etiology, Aspirin Bleeding. J. MacLean Smith and J. Mackinnon ; Bell's Palsy, Etiogogy, tomy for prevention of Pulmonary complications in Post operative and severely Debilitated patients. Joseph P. Atkins; Inaccuracy of four Chemical Procedures as Diagnostic tests for Cancer. Richard J. Henry, Sam Berkman, Marshal S. Little and Richard J. Winzler.

For Advertisement space in this Journal apply to: HEADLEY BROTHERS Ltd, 109 Kingsway London W C 2

Please mention The Journal of Laryngology when replying to advertisements 